\title{
Assessment of Groundwater Quality for Drinking and Irrigation Purpose: A Case Study of Guntur Channel Command Area, Andhra Pradesh, India
}

\author{
K. Sai Manogna ${ }^{*}$, A. Mani ${ }^{2}$, G. Ravi Babu ${ }^{3}$ and V. Radha Krishna Murthy ${ }^{4}$ \\ ${ }^{1}$ Department of SWE, College of Agricultural Engineering, Bapatla, 522101, India \\ ${ }^{2}$ College of Agricultural Engineering, Bapatla, 522101, India \\ ${ }^{3}$ Department of Soil and Water Engineering, CAE, Bapatla-522101, India \\ ${ }^{4}$ Department of Agronomy, College of Agriculture, Bapatla-522101, India
}

*Corresponding author

\begin{abstract}
A B S T R A C T
Keywords

Groundwater quality,

Drinking, Irrigation,

Command area

Article Info

Accepted:

15 October 2018

Available Online:

10 November 2018

The study was conducted to understand the ground water quality by using different irrigation water suitability indices in Guntur channel command area for drinking and irrigation purpose. Total twenty five ground water samples were collected during post and pre-monsoon season. Physicochemical parameters like $\mathrm{pH}$, electrical conductivity, calcium, magnesium, carbonates, bicarbonates, sodium, total dissolved solids, total suspended solids were analysed using standard procedures. The values obtained were compared with the standards of BIS and WHO. A comparison of groundwater quality parameters in relation to specified limits for drinking water shows that concentration of EC, bicarbonates, sodium, total dissolved solids exceeded the desirable limits in many samples. Water quality assessment revealed that Ananthavarapadu, Vatticherukuru, Parthipadu, Kondepadu, Pallapadu, Mutluru, Godavarru, Namburu, Garapadu, Etukuru, Suddapalli villages, water is not suitable for drinking and irrigation purposes.
\end{abstract}

\section{Introduction}

Ground water is one of the most important natural resources. Ground water as a natural resource and an element of the environment, used in human activities, is of dual character (Borevsky et al., 1989).

Groundwater is thought as one of the purest form of water available in nature that meets the overall demands of population. Ground water is the water present beneath earth's surface in soil pore spaces and in the fractures of rock formations. Ground water is the least polluted one, if it is polluted once difficult to retrieve it. Water quality is based on physical and chemical constituents due to weathering of parent rocks and anthropogenic activities.

Ground water is part of the rain water reaches the earth surface and percolates into the earth, during the percolation it comes into contact with a number of mineral present in the soil which may dissolved in the water. Contamination of ground water may occur by percolation of toxic substances through the soil to ground water (Sargaonkar et al., 2006). Due to rapid increase in industrialisation and 
urbanisation has increased the disposal of untreated effluents without any proper treatment. It is important to know the quality of water in any command area for better management of water resources.

The objective of the present study to know whether the ground water in Guntur channel command area is suitable for drinking and irrigation purpose. The water suitability for irrigation was calculated on the basis of SAR (Sodium Adsorption Ratio), Residual Sodium Carbonate (RSC), Kelly's ratio. To demonstrate the spatial variability of different physicochemical parameters of ground water quality spatial maps were developed using Arc GIS software.

\section{Study area}

The study area is the Guntur channel command area, Guntur, Andhra Pradesh. Channel was excavated for irrigation in left over patch in between Nagarjuna Sagar Project and Krishna Western Delta ayacut. It is a major irrigation scheme in Guntur district with starting point of channel at upstream of Prakasam barrage. The length of the channel is $47 \mathrm{Km}$. The benefited mandals are seven and thirty three villages. Tadepalli, Mangalgiri, Pedakakani, Guntur, Chebrolu, Vatticherukuru and Prathipadu. The annual minimum and maximum temperature are $15^{\circ} \mathrm{C}$ and $47^{\circ} \mathrm{C}$. The average rainfall in the Guntur district is $830 \mathrm{~mm}$.

\section{Materials and Methods}

Twenty five groundwater samples were collected from bore wells/hand pumps (in pre and post monsoon seasons at identical same locations in November (2017) and April (2018). Locations of sampling points were determined using a Global Positioning System (GPS) (Figure 1). Hand pumps were continuously pumped prior to ground water sampling to ensure that ground water to be sampled was representative of ground water aquifer. The samples were collected in $250 \mathrm{ml}$ plastic bottles. Two drops of toluene chemical was added to all water samples to prevent the microbial growth of bacteria and fungi. Collected samples were properly labelled and brought to laboratory for analysis. Samples were analyzed in the laboratory to measure the concentration of the quality parameters using American Public Health Association standard methods (APHA, 1995). $\mathrm{pH}, \mathrm{EC}, \mathrm{Ca}^{+2}, \mathrm{Mg}^{+2}$, $\mathrm{Na}^{+}, \mathrm{CO}_{3}^{-2}, \mathrm{HCO}_{3}^{-}$, total dissolved solids and Total suspended solids were the major ions in groundwater of the study area. Calcium and Magnesium concentrations were determined by Ethylenediamine tetraacetic acid (EDTA) titration using Eriochrome black-T as indicator.

Sodium concentration was determined by using flame photometer. Bicarbonate and Carbonate content was estimated by using acid-base titration method. Irrigation water quality Indices namely SAR, RSC, RSBC, KR, MAR, PI were calculated.

\section{Results and Discussion}

\section{Electrical conductivity $(\mathrm{dS} / \mathrm{m})$}

Electrical conductivity values ranged from 0.6 to $8.57 \mathrm{dS} / \mathrm{m}$ in post monsoon season and spatially varied between 0.87 to $8.99 \mathrm{dS} / \mathrm{m}$ in pre-monsoon. The EC values were higher during pre-monsoon compared to post monsoon season. The primary effect of high EC water on crop productivity is the incapability of the plant to compete with ions in the soil solution for water.

\section{pH}

The $\mathrm{pH}$ values varied from 6.85 to 7.97 during post monsoon season and ranged from 7.04 to 8.25 during pre-monsoon season (Fig. 2). 


\section{Carbonates}

The permissible limits of Carbonates in drinking water as prescribed by BIS were 75 $\mathrm{mg} / \mathrm{l}$. The carbonate values ranged from 0 to $12.31 \mathrm{mg} / \mathrm{l}$ during post monsoon season. All the command area villages recorded carbonates value within the acceptable limit. Carbonates values varied from 0 to 381.89 $\mathrm{mg} / \mathrm{l}$ during pre-monsoon (Fig. 3). Maximum values were recorded at Parthipadu mandal.

\section{Bicarbonates}

The bicarbonates values varied from 334.23 to $603.03 \mathrm{mg} / \mathrm{l}$ during post monsoon season in villages of channel command area and values ranged from 309.55 to $1036.80 \mathrm{mg} / \mathrm{l}$ during pre-monsoon season (Fig. 4). Higher values (813.3 to $1122.09 \mathrm{mg} / \mathrm{l})$ were observed in villages namely Kaza, Pedavadlapudi, Kondepadu and Ananthavarapadu during post monsoon period.

\section{Calcium}

The calcium content varied from 49.91 to $355.53 \mathrm{mg} / \mathrm{l}$ in the villages of Guntur channel command area during post monsoon season and values ranged from 44.55 to $168.38 \mathrm{mg} / \mathrm{l}$ during pre-monsoon season was depicted in Figure 5. Maximum values of calcium content (229.69 to $355.53 \mathrm{mg} / \mathrm{l}$ ) were noticed at Ananthavarapadu, Godavarru and Narakoduru villages during post monsoon season. Higher values of $\mathrm{Ca}$ hardness during post monsoon season are due to dissolution of $\mathrm{CaCO}_{3}$ by water recharge (Kupwade and Langde, 2013).

\section{Magnesium}

The magnesium content varied from 32 to $127.16 \mathrm{mg} / \mathrm{l}$ during post monsoon season and values ranged from 22.2 to $108.2 \mathrm{mg} / \mathrm{l}$ during pre-monsoon season (Fig. 6) Maximum values (90.57 to $127.16 \mathrm{mg} / \mathrm{l})$ were recorded at
Pedavadlapudi, Kaza, Kondepadu, Vejendla, Chamallamudi and Ananthavarapadu villages during post monsoon season. Magnesium concentration was lower during pre-monsoon season compared to post monsoon season because of recharging of water due to rains.

\section{Sodium}

Sodium content varied from 227.52 to 755.73 $\mathrm{mg} / \mathrm{l}$ during post monsoon season and values ranged from 227.97 to $2116.79 \mathrm{mg} / \mathrm{l}$ during pre-monsoon season (Fig. 7). Higher values were noticed (1443.52 to $2116.79 \mathrm{mg} / \mathrm{l})$ at villages namely Kondepadu, Yamarru, Ananthavarapadu and Chamallamudui during pre-monsoon season due to high evaporation, salts might have risen to surface. The permissible limit of sodium in drinking water as prescribed by BIS is $50 \mathrm{mg} / \mathrm{l}$. Sodium content values exceeded the acceptable limit in both the seasons. Hence, ground water in channel command area is unsuitable for drinking.

\section{Total dissolved solids}

The TDS values spatially varied from 385.11 to $5465.31 \mathrm{mg} / \mathrm{l}$ during post monsoon season and values ranged from 552 to $5755.51 \mathrm{mg} / \mathrm{l}$ in pre-monsoon season (Fig. 8). Maximum concentration of TDS (3525.23 to 5465.31 $\mathrm{mg} / \mathrm{l}$ ) was recorded in villages namely Etukuru, Ananthavarapadu and Chamallamudi during post-monsoon season. Similar trend was observed with higher values recorded in the same villages during pre-monsoon season.

\section{Total Suspended Solids}

The total suspended solids concentration was lower compared to all other parameters. The TSS values ranged from 0.009 to $2.05 \mathrm{mg} / \mathrm{l}$ during post monsoon season and varied from 0.92 to $3.39 \mathrm{mg} / \mathrm{l}$ during pre-monsoon season (Fig. 9). 
Fig.1 Location map of ground water sampling stations

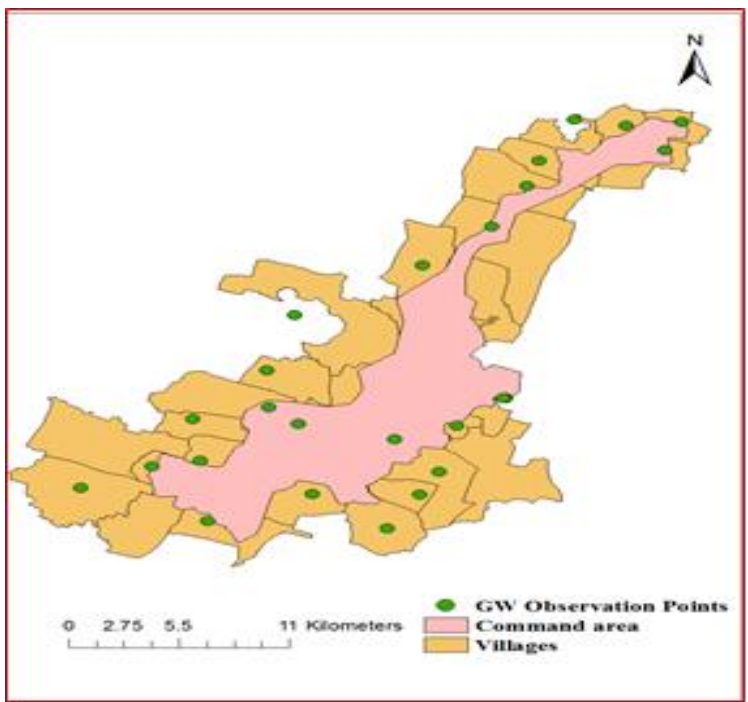

Fig.1 Spatial variation of EC in ground water of Guntur channel command area

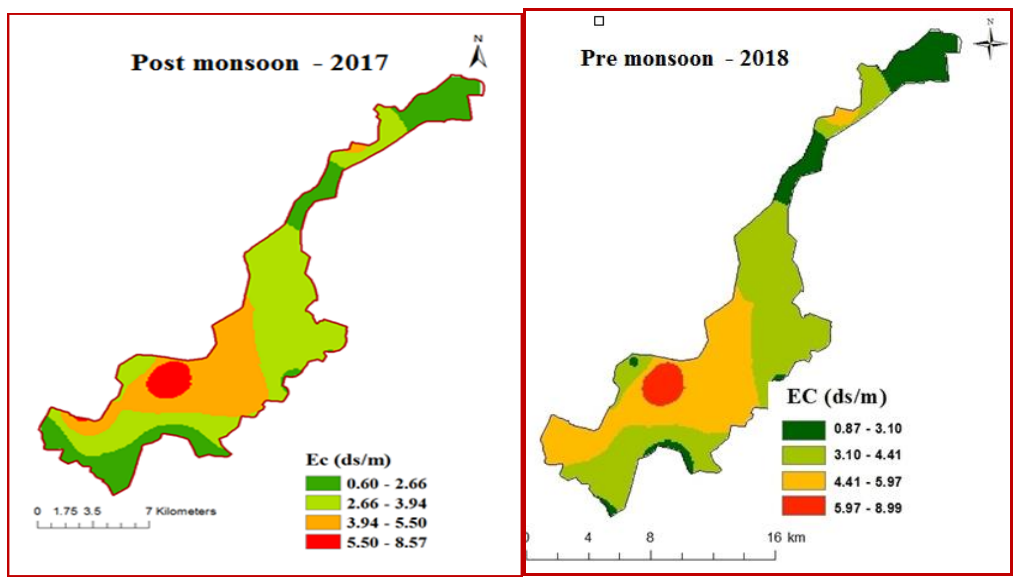

Fig.2 Spatial variation of $\mathrm{pH}$ in ground water of Guntur channel command area

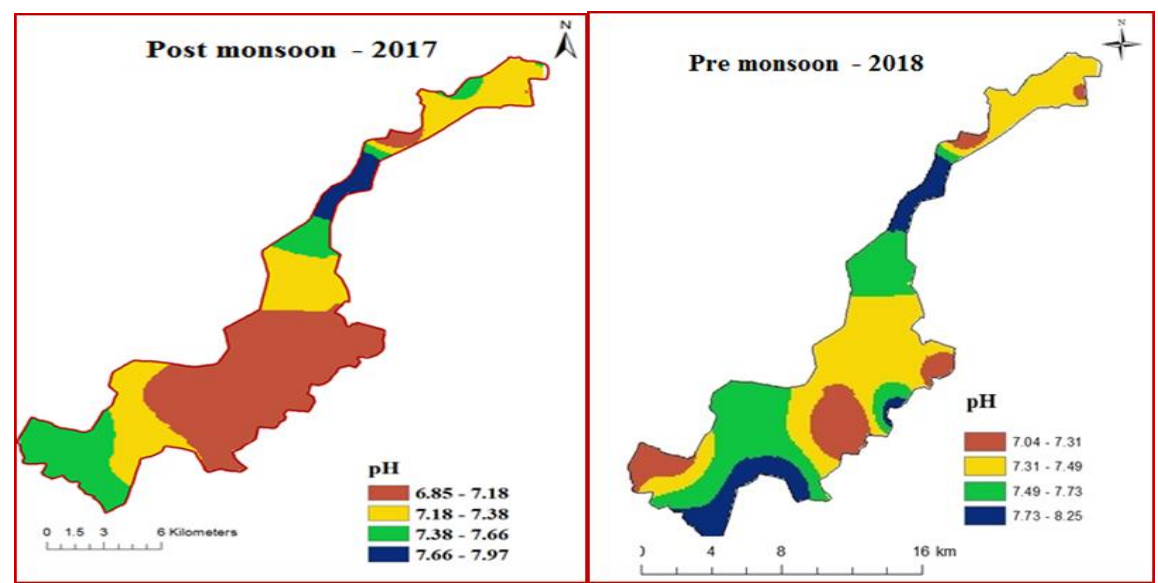


Fig.3 Spatial variation of carbonates in ground water of Guntur channel command area
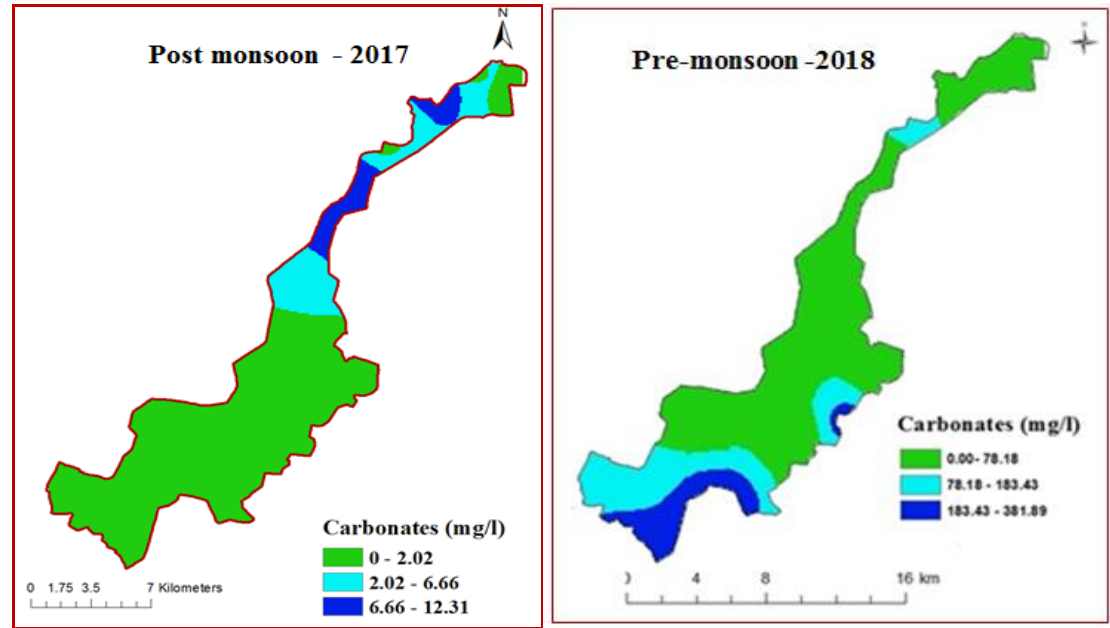

Fig.4 Spatial varaition of bicarbonates in ground water of Guntur channel command area

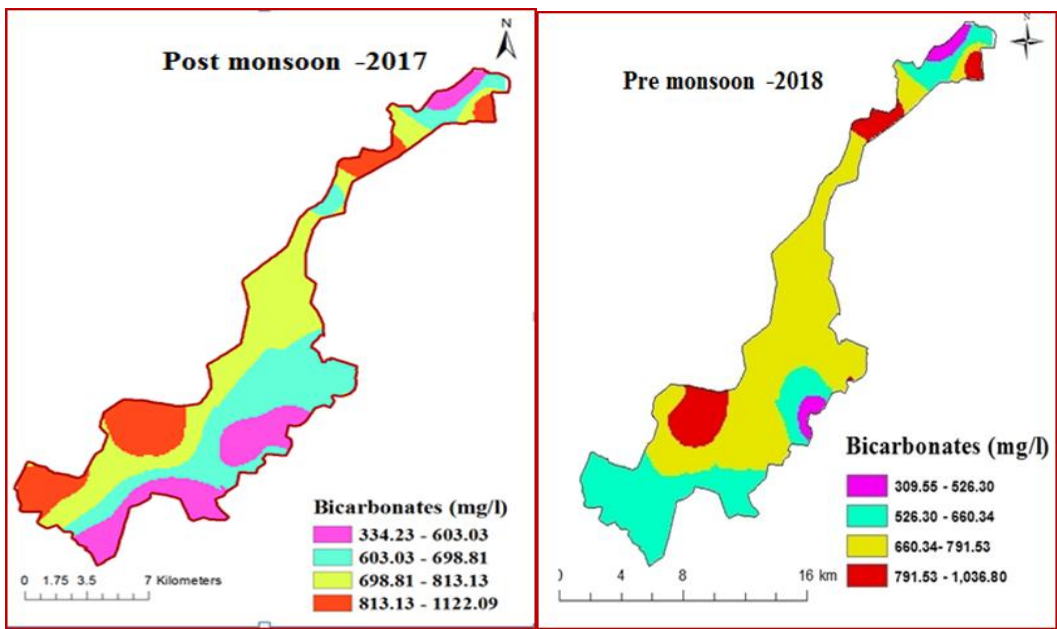

Fig.5 Spatial variation of calcium in ground water of Guntur channel command area

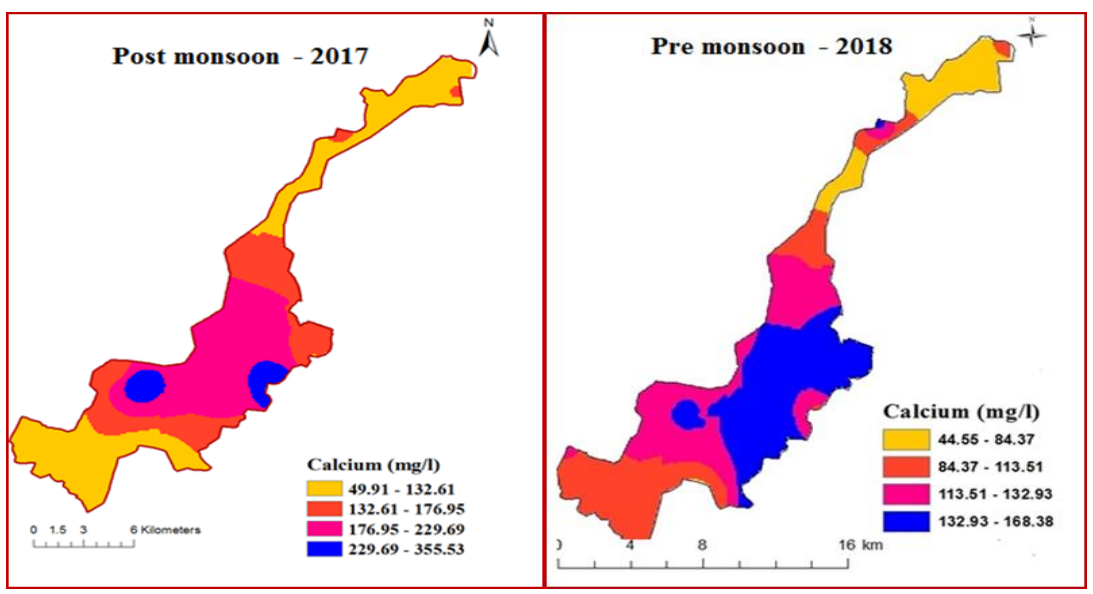


Fig.6 Spatial varaition of magnesium in ground water of Guntur channel command area

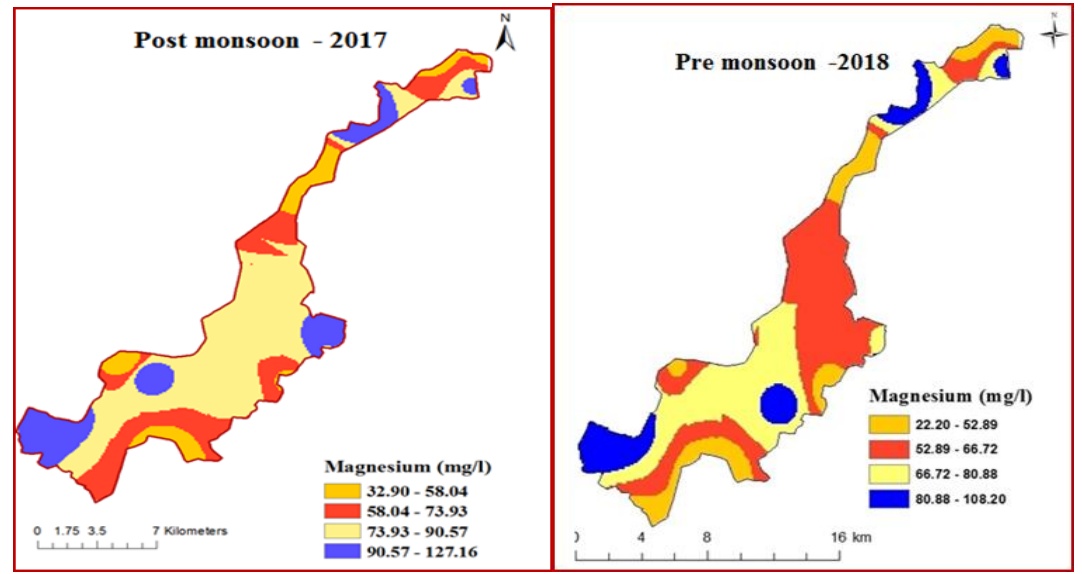

Fig.7 Spatial variation of sodium in ground water of Guntur channel command area

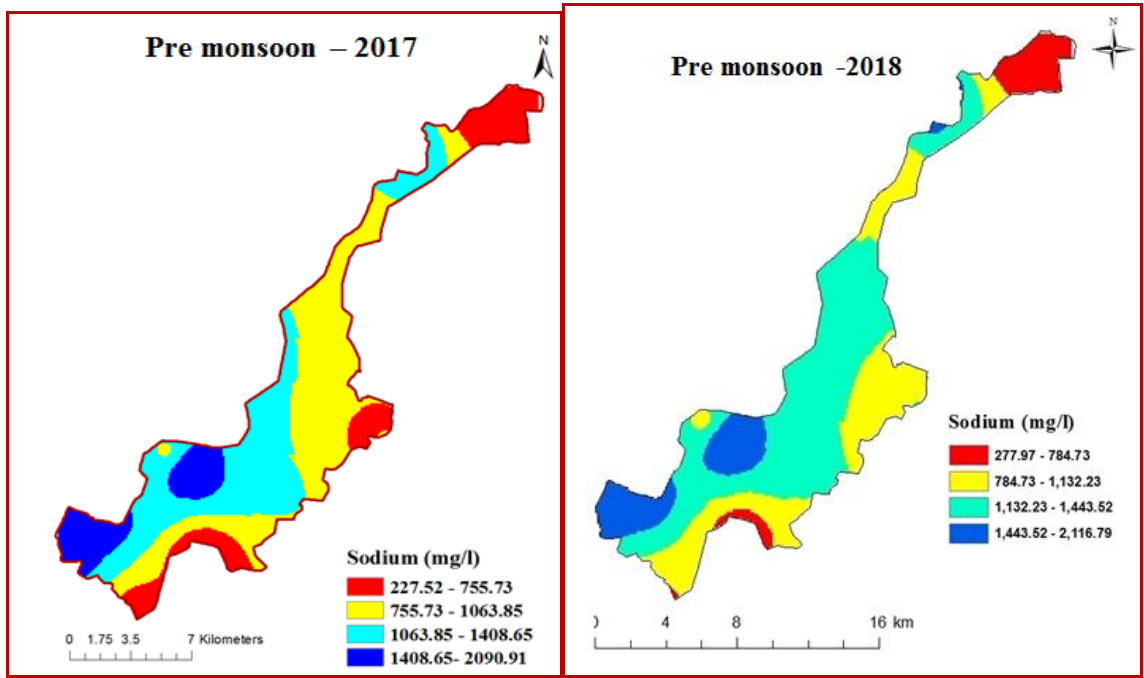

Fig.8 Spatial variation of TDS in ground water in Guntur channel command area

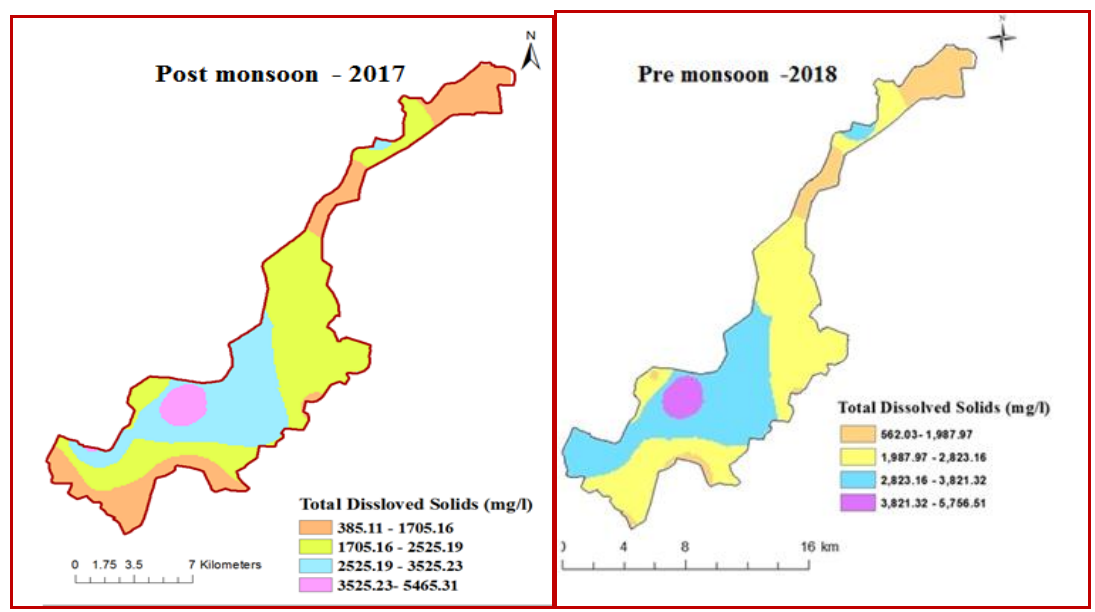


Fig.9 Spatial variation of TSS in ground water of Guntur channel command area
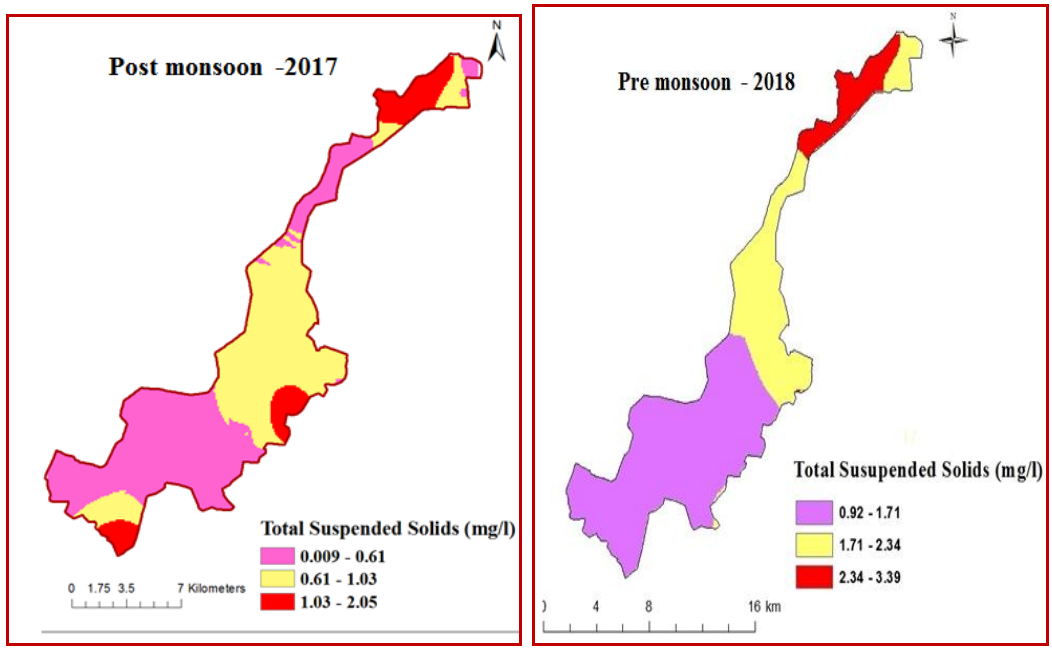

Table.1 Drinking water standards of Bureau of Indian Standards (BIS) and World Health Organization (WHO)

\begin{tabular}{|c|l|c|c|c|} 
S. No. & \multicolumn{1}{|c|}{ Parameters } & \multicolumn{2}{|c|}{ BIS } & \multirow{2}{*}{ WHO limit } \\
\hline & & $\begin{array}{c}\text { Acceptable } \\
\text { limit }\end{array}$ & $\begin{array}{c}\text { Maximum } \\
\text { limit }\end{array}$ & \\
\hline $\mathbf{1}$ & $\mathrm{pH}$ & $6.5-9.2$ & $6.5-9.2$ & $6.5-9.2$ \\
\hline $\mathbf{2}$ & EC & 300 & - & - \\
\hline $\mathbf{3}$ & $\begin{array}{l}\text { Total Dissolved solids } \\
\text { (mg/l) }\end{array}$ & 500 & 2000 & 500 \\
\hline $\mathbf{4}$ & Sodium (mg/l) & 50 & - & - \\
\hline $\mathbf{5}$ & Calcium (mg/l) & 75 & 200 & 75 \\
\hline $\mathbf{6}$ & Magnesium (mg/l) & 30 & 100 & 150 \\
\hline $\mathbf{7}$ & Carbonates (mg/l) & 75 & 200 & 75 \\
\hline $\mathbf{8}$ & Bicarbonates (mg/l) & 30 & - & 150 \\
\hline $\mathbf{9}$ & Total Suspended Solids & - & - & 500 \\
\hline
\end{tabular}

Table.2 Classification of ground water based on electrical conductivity

\begin{tabular}{|c|c|c|c|c|}
\hline \multirow{2}{*}{$\begin{array}{c}\mathrm{EC} \\
(\mathrm{dS} / \mathrm{m})\end{array}$} & \multirow[t]{2}{*}{ Class } & \multirow{2}{*}{$\begin{array}{l}\text { Suitability for } \\
\text { irrigation }\end{array}$} & \multicolumn{2}{|c|}{ Samples falling in two dissimilar seasons } \\
\hline & & & $\begin{array}{l}\text { Post monsoon } \\
\text { (\% of samples) }\end{array}$ & $\begin{array}{l}\text { Pre-monsoon } \\
\text { (\% of samples) }\end{array}$ \\
\hline$<0.25$ & $\mathrm{C}_{1}$ & Very good water & - & - \\
\hline $0.25-0.75$ & $\mathrm{C}_{2}$ & Good water & $8 \%$ & $4 \%$ \\
\hline $0.75-2.25$ & $\mathrm{C}_{3}$ & Doubtful & $32 \%$ & $28 \%$ \\
\hline$>2.25$ & $\mathrm{C}_{4}$ & Not useful & $60 \%$ & $68 \%$ \\
\hline
\end{tabular}


Table.3 Classification of ground water based on Sodium Adsorption Ratio (SAR)

\begin{tabular}{|c|c|c|c|}
\hline \multirow{2}{*}{$\begin{array}{c}\text { SAR } \\
\text { value }\end{array}$} & \multirow[t]{2}{*}{ Class } & \multicolumn{2}{|c|}{ Samples falling in two dissimilar seasons } \\
\hline & & Post-monsoon (\% of samples) & Pre-monsoon (No. of samples) \\
\hline 10 & Excellent & $28 \%$ & $20 \%$ \\
\hline $10-18$ & Good & $28 \%$ & $36 \%$ \\
\hline $18-26$ & Fair & $28 \%$ & $28 \%$ \\
\hline$>26$ & Poor & $16 \%$ & $16 \%$ \\
\hline
\end{tabular}

Table.4 Summary statistics of various ground water quality parameters during post monsoon season

\begin{tabular}{|c|l|c|c|c|c|}
\hline S. No & \multicolumn{1}{|c|}{ Parameters } & Mean & Min & Max & SD \\
\hline $\mathbf{1}$ & EC & 3.56 & 0.61 & 15.6 & 3.27 \\
\hline $\mathbf{2}$ & pH & 7.28 & 6.85 & 8.19 & 0.34 \\
\hline $\mathbf{3}$ & Calcium(mg/l) & 133.44 & 24.0 & 384.0 & 81.69 \\
\hline $\mathbf{4}$ & Magnesium(m/l) & 80.93 & 4.8 & 300.0 & 59.62 \\
\hline $\mathbf{5}$ & Carbonates(mg/l) & 7.44 & 0.0 & 120.0 & 25.30 \\
\hline $\mathbf{6}$ & Bicarbonates(m/l) & 712.48 & 292.8 & 1122.4 & 248.63 \\
\hline $\mathbf{7}$ & sodium(mg/l) & 1033.00 & 150.0 & 3300.0 & 730.25 \\
\hline $\mathbf{8}$ & Total suspended solids & 0.68 & 0.0 & 2.2 & 0.71 \\
\hline $\mathbf{9}$ & TDS(mg/l) & 2281.22 & 390.2 & 5491.2 & 2616.49 \\
\hline $\mathbf{1 0}$ & SAR & 17.24 & 4.12 & 36.8 & 9.39 \\
\hline $\mathbf{1 1}$ & RSC & -1.29 & -15.07 & 9.62 & 6.14 \\
\hline $\mathbf{1 2}$ & RSBC & 5.20 & -11.07 & 12.09 & 4.78 \\
\hline $\mathbf{1 3}$ & Kellys Ratio & 3.82 & 1.0 & 19.7 & 3.60 \\
\hline $\mathbf{1 4}$ & MAR & 48.00 & 17.0 & 82.0 & 15.10 \\
\hline $\mathbf{1 5}$ & PI & 81.00 & 64.0 & 104.0 & 9.14 \\
\hline
\end{tabular}

Table.5 Summary statistics of various ground water quality parameters for pre-monsoon season

\begin{tabular}{|c|l|c|c|c|c|}
\hline S. No & \multicolumn{1}{|c|}{ Parameters } & Mean & Min & Max & SD \\
\hline $\mathbf{1}$ & EC & 4.09 & 0.72 & 15.9 & 3.2 \\
\hline $\mathbf{2}$ & pH & 7.48 & 7.0 & 8.5 & 0.41 \\
\hline $\mathbf{3}$ & Calcium(mg/l) & 110.48 & 12.0 & 288.0 & 61.8 \\
\hline $\mathbf{4}$ & Magnesium(mg/l) & 72.53 & 7.2 & 235.0 & 50.36 \\
\hline $\mathbf{5}$ & Carbonates(mg/l) & 48.0 & 0.0 & 480.0 & 116.19 \\
\hline $\mathbf{6}$ & Bicarbonates(mg/l) & 697.84 & 244.0 & 1159.0 & 242.14 \\
\hline $\mathbf{7}$ & sodium(mg/l) & 1173 & 250.0 & 3675.0 & 756.74 \\
\hline $\mathbf{8}$ & Total suspended solids & 1.98 & 0.8 & 3.4 & 0.75 \\
\hline $\mathbf{9}$ & TDS(mg/l) & 2618.62 & 460.8 & 10176 & 2056.79 \\
\hline $\mathbf{1 0}$ & SAR & 17.61 & 5.1 & 40.1 & 9.06 \\
\hline $\mathbf{1 1}$ & RSC(meq/l) & 1.04 & -14 & 20.3 & 7.18 \\
\hline $\mathbf{1 2}$ & RSBC(meq/l) & 5.48 & -12 & 15.9 & 5.59 \\
\hline $\mathbf{1 3}$ & Kellys Ratio & 5.42 & 0.98 & 31.7 & 5.82 \\
\hline $\mathbf{1 4}$ & MAR & 48.98 & 9.09 & 83.76 & 17.87 \\
\hline $\mathbf{1 5}$ & PI & 85.42 & 57.55 & 104.15 & 9.88 \\
\hline
\end{tabular}


Ground water samples in post and premonsoon season were classified based on electrical conductivity

Only $8 \%$ of samples were found to be suitable for irrigation during post monsoon season and $60 \%$ of water samples fall under not suitable for irrigation.

$28 \%$ of ground water samples were excellent in quality during post monsoon and 20\% samples were excellent during pre-monsoon season (Table 3). Higher SAR values (poor) were recorded at Etukuru, Garapadu, Namburu and Parthipadu (36.8).

On Comparing various parameters in two seasons, pre-monsoon analysed parameters namely calcium, magnesium, bicarbonates have lower values compared to post monsoon. During post monsoon season, the concentration of chemical parameters showed decreased trend due to dilution effect by the surface run-off received during rainfall (Srivastava et al., 2011).

The ground water in Guntur channel command area varied from neutral to alkaline during post-monsoon season. Sodium, Bicarbonates, Total dissolved solids exceeded the permissible limits of BIS and require treatment before its utilization. According to SAR classification $28 \%$ samples fall under excellent quality during post monsoon season and decreased to $20 \%$ of samples in premonsoon season. Quality assessment for irrigation suitability shows that the groundwater in Ananthavarapadu, Vatticherukuru, Parthipadu, Kondepadu, Pallapadu, Mutluru, Godavarru, Namburu, Garapadu, Etukuru, Suddapalli villages is not suitable for drinking and irrigation purposes. High values of salinity, residual sodium carbonate, residual sodium bicarbonate and sodium adsorption ratio at some villages restricts the suitability of groundwater for agricultural purposes and demands special management plan for the area.

\section{References}

Arivarasi, R and Ganesan, M. 2017. Seasonal variation in ground water quality and its suitability for drinking and agriculture A case study in Kancheepuram region, Tamil Nadu, India. Global NEST Journal.19 (1): 131-139.

Arya, S., Kumar, V., Minakshi and Anshu, D. 2011. Assessment of groundwater quality: A case study of Jhansi city, Uttarpradesh, India. International Multidisciplinary Research Journal. 1(7): 11-14.

Ganapathi, S.R., Subramanian, V and Sukumar, S. 2011. Pre and post monsoon variation in physic-chemical characteristics in Ground water quality parts of Tirunelveli District, Tamil Nadu, India. International Journal of Geomatics and Geosciences. 2(1): 300310.

Reddy, K.S 2013. Assessment of irrigation water quality for Bhaskar Rao kunta watershed, Nalgonda district, India. International Journal of Water Resources and Environmental Engineering. 5(7): 418-425.

Sargaonkar, A and Deshpande, V. 2003. Development of an overall index of pollution for surface water based on a general classification scheme in Indian context, Environmental Monitoring and Assessment. 89: 43-67.

Srivastava, P.K., Mukherjee, S., Gupta, M and Singh, S.K. 2011. Characterizing monsoonal variation on water quality index of River Mahi in India using Geographical Information System, Water Quality Expo Health. 2: 193203.

Sudhakar, G., Swarnalatha, G., Brahmaji Rao, $\mathrm{P}$ and Venkataratnamma, V. 2014. 
Water quality analysis in Acharya Nagarjuna University Region, Guntur, A. P, India. IOSR: Journal of Environmental Science, Toxicology and Food Technology. 8(9): 37-40.

Thirupathaiah, M., Samatha, Ch and Sammaiah, Ch. 2012. Analysis of water quality using physico-chemical parameters in lower Manair reservoir of
Karimnagar district, Andhra Pradesh. International Journal of Environmental Sciences. 3(1): 172-180.

Trivedi, P., Bajpai, A and Thareja, S. 2009. Evaluation of Water Quality: PhysicoChemical Characteristics of Ganga River at Kanpur by using Correlation Study. Nature and science. 1(6): 91-94.

\section{How to cite this article:}

Sai Manogna, K., A. Mani, G. Ravi Babu and Radha Krishna Murthy, V. 2018. Assessment of Groundwater Quality for Drinking and Irrigation Purpose: A Case Study of Guntur Channel Command Area, Andhra Pradesh, India. Int.J.Curr.Microbiol.App.Sci. 7(11): 1849-1858. doi: https://doi.org/10.20546/ijcmas.2018.711.209 